\title{
Wyoming big sagebrush seed production from mined and unmined rangelands
}

\author{
D.T. BOOTH, Y. BAI, AND E. E. ROOS
}

Authors are Rangeland Scientist, USDA-ARS, High Plains Grasslands Res. Sta., 8408 Hildreth Road, Cheyenne, Wyo., 82009 (e-mail: tbooth@lamar.colostate.edu); Assistant Professor, Dept. Plant Sciences, Univ. Saskatchewan, 51 Campus Drive, Saskatoon, Sask. S7N 5A8, Canada (e-mail: yuguang.bai@usask.ca) and Assistant Area Director, USDA-ARS, Northern Plains Area, 1201 Oakridge Dr., Fort Collins, Colo., 80525, formerly Research Leader and Plant Physiologist, National Seed Storage Laboratory (e-mail: roose@ars.usda.gov).

\begin{abstract}
Wyoming Coal Rules and Regulations require shrubs be returned to mined land and that revegetation "...be self renewing." We evaluated seed production and seed quality of Wyoming big sagebrush (Artemisia tridentata Nutt. ssp. wyomingensis (Beetle \& Young)) by measuring the effect of mining, herbivory, and environmental modification on seed production at 5 sites on the Dave Johnston Coal Mine near Glenrock, Wyo. Mined-land stands ranged in age from 5 to $>20$ years. Single sagebrush plants on mined, and adjacent unmined land were treated by: (1) fabric mulch around the base, (2) windbreak on the north and west, (3) both mulch and windbreak, and (4) neither windbreak nor mulch. Plants were fenced and compared with unfenced, untreated, neighboring plants. Seeds were harvested for 3 years and data were collected on seed-stalk numbers, bulk weight of seeds produced, and seed quality. Fenced mined-land plants produced several times more seeds than fenced plants on adjacent unmined land. There was no difference in seed quality. Treatments to modify the plant environment resulted in some benefits but fencing had a greater effect on seed-quality parameters than did planned treatments. We conclude the sagebrush seed-production potential on reclaimed lands such as those of the Dave Johnston Coal Mine is equal to, and often several times greater than that of adjacent unmined lands. However, browsing by wild ungulates can eliminate the mined-land yield advantage.
\end{abstract}

Key Words: environmental effects, seed quality, big game, soil moisture, ecological restoration

Wyoming began legislating the return of woody plants to mined lands in 1973 with the Surface Mining Control and Reclamation Act. The act simply required shrubs be included in reclamation seed mixtures. Current Wyoming law requires $20 \%$ of eligible lands be restored to shrub patches not less than 0.02 ha

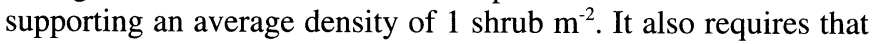
revegetation “... be self-renewing ..." (DEQ-LQD 1995, WEQC 1995, Federal Register 1996).

The work was supported in part by the Abandoned Coal Mine Lands Research Program at the University of Wyoming. Support was administered by the Wyoming Dept. of Environmental Quality from funds returned to Wyoming from the Office of Surface Mining of the U.S. Dept. of Interior. The authors thank C. Skilbred, Sr. Environmental Scientist for Glenrock Coal Company for cooperation in this study; L.W. Griffith for coordinating technical assistance; and Drs. J.E. Anderson, D. Belesky, and B.L. Welch for helpful suggestions on the manuscript.

Manuscript accepted 3 Aug. 02.

\section{Resumen}

El reglamento y normas de explotación de Carbón en Wyoming exige que los arbustos se regresen a la tierra minada y que esa revegetación "sea auto renovable". Evaluamos la producción y calidad de semilla del "Wyoming big sagebrush" (Artemisia tridentata Nutt. ssp. wyomingensis (Beetle \& Young)) midiendo el efecto del minado, la herbivoría y la modificación ambiental en la producción de semilla en 5 sitios en la mina de carbón Dave Johnston situada cerca de Glenrock, Wyo. Las poblaciones en el terreno minado variaron de 5 a más de 20 años. Plantas individuales en el terreno minado y en un terreno adyacente sin minar fueron tratadas con: (1) acolchado con tela alrededor de la base , (2) cortina rompeviento en el norte y oeste, (3) ambos, acolchado y cortina rompeviento y (4) ni acolchado ni cortina rompeviento. Las plantas fueron cercadas y comparadas con plantas vecinas sin cercar y sin tratar. Las semillas fueron cosechadas durante 3 años y se colectaron datos sobre el número de tallos florales, peso bruto de las semillas producidas y calidad de la semilla. Las plantas cercadas en terreno minado produjeron varias veces mas semilla que las plantas cercadas en terrenos adyacentes sin minar. No hubo diferencia en la calidad de la semilla. Los tratamientos para modificar el ambiente de la planta resultaron en algunos beneficios, pero el cercar las plantas tuvo un mayor efecto en los parámetros de calidad de semilla que los tratamientos planeados. Concluimos que el potencial de producción de semilla de "Sagebrush" en terrenos minados, tal como los presentes en la mina de carbón Dave Johnston es igual a, y a veces varias veces mayor, la producida en terrenos adyacentes sin minar. Sin embargo, el ramoneo por ungulados silvestres puede eliminar la ventaja que da los terrenos minados.

Since 1973, attention has been focused on shrub seeding methods, re-establishment densities, and dominant species (WEQC 1995, Booth et al. 1999). Measurement of shrub stand regeneration on mined lands has received little attention. No studies have measured mined-land seed production or quality although surveys by Gores (1995) and Lyford (1995) give some information on seedling recruitment.

We tested the hypothesis that Wyoming big sagebrush (Artemisia tridentata Nutt. ssp. wyomingensis (Beetle \& Young) seed production and quality on mined land was not different from that of adjacent unmined land. We also tested environment-modifying treatments as potential mitigation options should minedland seed production be found deficient. 


\section{Materials and Methods}

\section{Site Description}

Our study was conducted on the Dave Johnston Coal Mine, $40 \mathrm{~km}$ east of Casper, Wyo. (42.992 N, 105.851 W). The mine is at an elevation of $1,646 \mathrm{~m}$, has a mean annual precipitation of $328 \mathrm{~mm}$ and a mean annual temperature of $8.8^{\circ} \mathrm{C}$ (Martner 1986, Owenby and Ezell 1992). The site averages 123 frost-free days per year. Soil parent material is Cretaceous clay shale (Young and Singleton 1977). Five sites were located on the mine where mined-land sagebrush stands were in close proximity to stands of sagebrush on unmined rangeland (Table 1).

Table 1. Description of sagebrush study sites on the Dave Johnston Coal Mine.

\begin{tabular}{lcllll}
\hline \hline & \multicolumn{3}{c}{ Mined Stand $^{1}$} & & \\
\cline { 2 - 3 } Site Name & Age & Slope & Aspect & & Comments \\
\hline & $(\mathrm{yrs})$ & & & \\
Fuel Island & $>20$ & gentle & West & & Unmined site was grazed \\
Entry 50 & 16 & gentle & West & & Unmined site was grazed \\
110 School & 12 & moderate & North & None \\
60 Badger & 10 & very gentle & Southwest & Unmined site was mod. sloping \\
4 School & 5 & moderate & West & & Unmined site was mostly level \\
\hline
\end{tabular}

Unless otherwise noted, slope, aspect, and livestock grazing are the same for the mined and unmined stands. The distance between paired mined and unmined stands was estimated as $\leq 100 \mathrm{~m}$ and elevational differences were estimated at $\leq 56 \mathrm{~m}$.

\section{Treatments and Experimental Design}

The study was begun July 1995, by selecting 48 plants of similar size at each site $(24$ on mined land and 24 on unmined rangeland) (Table 2). Single sagebrush

Table 2. Experimental variables used in sagebrush seed production study.

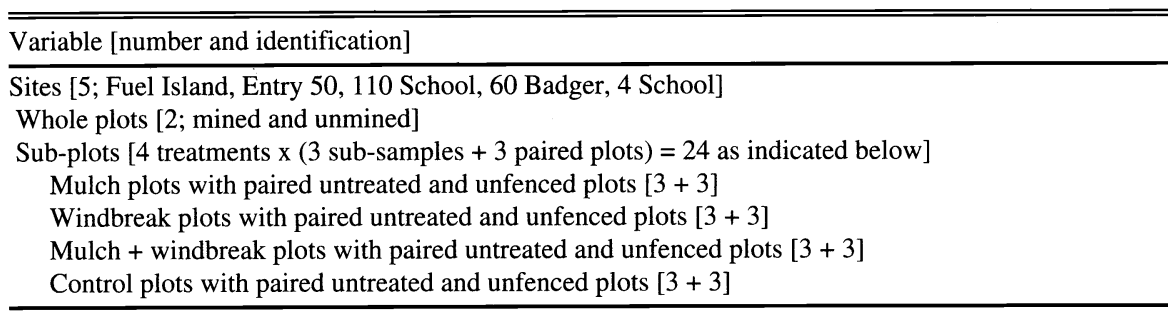

plants were treated as follows: (1) understory plants were cut to ground level and a square, $1 \mathrm{~m}^{2}$-piece of fabric mulch (Appleton et al. 1990) was installed around the base of the plant, (2) a windbreak of fabric mulch was erected on the north and west side of the plant, (3) both mulch and a windbreak were installed, and (4) neither windbreak nor mulch (control). The experimental design was a split plot, 2 x 2 factorial replicated among the 5 sites with whole plots being land type (mined vs. unmined) and sub-plots being mulch and windbreak treatments with 3 sub-samples (individual plants).

The plants selected for treatment were surrounded by a $1-\mathrm{m}^{2} \times 1 \mathrm{~m}$-high fence of $2.54-\mathrm{cm}$ wire net, then paired with an unfenced and untreated adjacent plant (Table 2). Our test necessarily included an evaluation of herbivory and environmental modification by the wire net because we needed to protect experimental plants and we needed to measure the effect of protective measures.

Soil moisture data were obtained from gypsum blocks buried to $10 \mathrm{~cm}$ below the soil surface and beneath the canopy of treated plants. The blocks were read mid- month, May through September, 1996 through 1998. The data were analyzed by month across the 3 years of the study.

Seeds were harvested annually in late October or early November 1996, through 1998. Data collected included number of steins $\mathrm{sec}^{-1} \mathrm{~m}^{-2}$ PAR) and germination counted at 7 and 14 days (Booth and Bai 1999). At the end of the test ungerminated seeds were squeezed to determine which were firm or rotten. Firm seeds were counted as dormant. Quality tests were conducted using slant boards (Jones and Cobb 1963) and seed vigor evaluated by measuring seedling axial length after 14 days of incubation (Booth and Griffith 1994).

\section{Statistical Analysis}

We used the "Mixed" procedure in SAS to test for differences among variables and the "differences" option to compare leastsquare means (Littell et al. 1996, SAS 1996). Protective fencing was evaluated in separate analyses as a sub-plot effect (Table 3). Data for each year were analyzed separately in both analyses because differences due to year were expected and separate analyses by year reduces the number of interactions that must be evaluated (Table 3). The analysis for fenced plots compares effects of land, mulch, and windbreak among plants with protective fencing for each of 3 years. The analysis for unfenced plots compares the effect of land and fence (for the same 3 years) using fenced and unfenced control plants (no mulch or windbreak) (Table 3). The separate analyses will be reported under separate headings.

G.D. Booth (1987) observed that "Too often, ...researchers let the simplicity of the statistical test replace their own reasoned thought." Certain situations require a yes or no answer. Often, as in this study, the objective is to measure the degree of influence. To aid readers in judging the relative influence of our test variables and their interactions we report F-statistics as observed significance levels (OSLs) and we give the corresponding degrees of freedom (df). Low sample numbers can lead to concluding that there is no effect when there is, and large sample numbers can result in "significant" differences that have no meaning (Booth 1987).

\section{Results}

seed stalks and bulk weight of seeds produced per plant; and seed weight, moisture content at harvest, germination, and seedling vigor. Seed quality tests used 20 seeds per plant or the maximum number of seeds available if $<20$. Seed moisture at harvest was determined as described by Bai et al. (1997). Seeds were imbibed at $5^{\circ}$ $\mathrm{C}$ for 4 days followed by incubation at $20^{\circ}$ C with 12 hours of light (65.9 microein-

\section{Seed Stalk Numbers}

Fenced

None of the test variables affected seed stalk numbers. (The OSLs for all variables and interactions were $P>0.20$ except land in $1996(P=0.16)$, and mulch $(P=0.12)$ and windbreak $(P=0.10)$ in 1997 ; df: land $=4$, mulch $=104$, windbreak $=104$.) 
Table 3. Example programs, with model statements, as submitted to SAS for fenced, and fencedvs-unfenced plot analysis.

\begin{tabular}{|c|c|}
\hline Fenced & Fenced vs. Unfenced \\
\hline $\begin{array}{l}\text { proc mixed; } \\
\text { class site land mulch windbreak replication; } \\
\text { model bulk weight = } \\
\text { land } \\
\text { mulch } \\
\text { land } x \text { mulch } \\
\text { land } x \text { windbreak } \\
\text { land } x \text { mulch } x \text { windbreak; } \\
\text { random site site } x \text { land; } \\
\text { Ismeans land mulch } x \text { windbreak } \\
\text { land } x \text { mulch } x \text { windbreak / difference; } \\
\text { run; }\end{array}$ & $\begin{array}{l}\text { proc mixed; } \\
\text { class site land fence replication; } \\
\text { model bulk weight = } \\
\text { fence } \\
\text { land } \\
\text { land } x \text { fence; } \\
\text { random site site } x \text { land; } \\
\text { Ismeans fence land x fence / difference; } \\
\text { run; }\end{array}$ \\
\hline
\end{tabular}

\section{Unfenced vs Fenced}

Fenced plants produced greater seedstalk numbers than unfenced plants all 3 years (Table 4). (The OSLs for land and the land $x$ fence interaction $(48 \mathrm{df})$ were $P$ $>0.20$ for all comparisons.)

\section{Seed Yield per Plant (Bulk Weight) Fenced}

Land affected seed yield all 3 years, windbreak in 2 years, and mulch only in 1996 as part of a 3-way interaction (Table 5).

\section{Unfenced vs Fenced}

The OSL for the land $x$ fence interaction (48 df) was $\mathrm{P}<0.05$ in all 3 years and protected plants on mined land always ranked first, yielding 3 to 6 times more seed than protected plants on unmined land (Fig. 1).

\section{Seed Quality Analysis}

Average Seed Weight - Fenced

Average seed weight had some influence of land x mulch in 1997 and mulch in 1998 (Table 6).

\section{Average Seed Weight - Unfenced vs Fenced}

Fenced plants produced heavier seeds in 1996 and 1997, but not in 1998 (Table 4).

\section{Seed Moisture - Fenced}

Seed moisture at harvest was similar among variables. (Land $\mathrm{x}$ mulch (104 df) OSL in 1997 was $P=0.10$, for all other effects the OSLs were $P>0.20$. Means for the interaction ranged from $5.0 \%$ for mined land with mulch, to $6.3 \%$ for mined land without mulch.)

Seed Moisture - Unfenced vs Fenced

Fenced plants had higher seed moisture than unfenced plants all 3 years (Table 4).

\section{Seed Germination - Fenced} effect on germination or do Mean germination percentages ranged between 39 and $92 \%$ on unmined land, and between 77 and $92 \%$ on mined land. (There was a 3-way interaction of land $x$ windbreak $x$ mulch $(21 \mathrm{df})$ in $1996(\mathrm{P}=$ 0.02). In 1997, the OSLs were all $P>0.18$ (df: land $=3$, other variables $=21$ ), and in each pair of means. and windbreak ${ }^{1}$.
1998 there was a land $\mathrm{x}$ windbreak 2-way interaction $(\mathrm{P}=0.02)$.)

Percentage dormant seeds (those that did not germinate but remained firm through the test period) ranged from 3.5 to $23.7 \%$ in $1996,1.0$ to $6.8 \%$ in 1997 , and 1.2 to 8.4 in 1998. (Land $\mathrm{x}$ windbreak in 1996 and 1998, and mulch $\mathrm{x}$ windbreak in 1996 had OSLs where $P=0.12$; all other effects had OSLs $>0.20$ (df the same as for germination).)

\section{Seed Germination - Unfenced vs Fenced}

Fencing did not affect germination or the percentage of dormant seeds. (The OSLs were $\mathrm{P}=0.12$ for a 1998 land $\mathrm{x}$ fence interaction ( $5 \mathrm{df}$ ), and $P>0.20$ for all others (df:land $=4$, others $=5$ ). ) Mean germination percentages for main effects (land, fence) ranged from 76 to $90 \%$ among the 3 years. The corresponding mean dormancy percentages ranged from 2.0 to $6.6 \%$. OSLs for all effects and all years were $>0.19$.

Table 4. Effect of protective fencing on means of sagebrush seed stalks per plant, weight of sagebrush seeds, and seed moisture 1996 to 1998 . The observed significance level (OSL) is given for

\begin{tabular}{|c|c|c|c|c|c|c|}
\hline \multirow[t]{2}{*}{ Variable } & \multicolumn{2}{|c|}{1996} & \multicolumn{2}{|c|}{1997} & \multicolumn{2}{|c|}{1998} \\
\hline & Fenced & Unfenced & Fenced & Unfenced & Fenced & Unfenced \\
\hline Number Seed-stalks & 22 & 4 & 56 & 10 & 76 & 15 \\
\hline $\operatorname{OSL}(\mathrm{df}=48)$ & \multicolumn{2}{|c|}{$\mathrm{P}<0.01$} & \multicolumn{2}{|c|}{$\mathrm{P}<0.01$} & \multicolumn{2}{|c|}{$\mathrm{P}<0.01$} \\
\hline Seed Wt (mg/seed) & 0.1507 & 0.0708 & 0.2483 & 0.1422 & 0.2325 & 0.1916 \\
\hline $\operatorname{OSL}(\mathrm{df}=48)$ & \multicolumn{2}{|c|}{$P=0.01$} & \multicolumn{2}{|c|}{$\mathrm{P}<0.01$} & \multicolumn{2}{|c|}{$P=0.29$} \\
\hline Seed Moisture (\%) & 3.9 & 1.3 & 5.6 & 3.1 & 4.0 & 2.5 \\
\hline $\operatorname{OSL}(\mathrm{df}=48)$ & \multicolumn{2}{|c|}{$\mathrm{P}<0.01$} & \multicolumn{2}{|c|}{$\mathrm{P}<0.01$} & \multicolumn{2}{|c|}{$\mathrm{P}=0.02$} \\
\hline
\end{tabular}

Table 5. Mean bulk weight of sagebrush seeds per plant by year as affected by type of land, mulch,

\begin{tabular}{llccc}
\hline \hline Year & Land Status & Mulch & Wind-break & Bulk Weight Seeds \\
\hline \multirow{3}{*}{1996} & & & & $(\mathrm{~g})$ \\
& Mined & yes & no & $25.5 \mathrm{a}$ \\
& Mined & no & yes & $21.8 \mathrm{ab}$ \\
& Mined & no & no & $13.0 \mathrm{~b}$ \\
& Mined & yes & yes & $12.7 \mathrm{~b}$ \\
& Unmined & yes & yes & $4.3 \mathrm{~b}$ \\
& Unmined & yes & no & $3.9 \mathrm{~b}$ \\
& Unmined & no & no & $3.1 \mathrm{~b}$ \\
& Unmined & no & yes & $2.4 \mathrm{~b}$ \\
& Mined & - & no & $29.9 \mathrm{a}$ \\
& Mined & - & yes & $20.1 \mathrm{~b}$ \\
& Unmined & - & yes & $8.6 \mathrm{~b}$ \\
& Unmined & - & no & $6.0 \mathrm{~b}$ \\
& Mined & - & - & $19.1(\mathrm{P}=0.10)$ \\
& Unmined & - & - & 4.4 \\
\hline
\end{tabular}

Observed Significance Level: 1996 land $\mathrm{x}$ mulch $\mathrm{x}$ windbreak $\mathrm{P}=0.06 ; 1997$ land $\mathrm{x}$ windbreak $\mathrm{P}=0.07$; and 1998 land $P=0.10 ; \mathrm{df}$ : land $=4$, windbreak $=102$, mulch $=102$, interactions $=104$. Means within a year followed by the same letter are not different at $\mathrm{P}<0.05$ as indicated by differences in least-square means within the "Mixed" statistical procedure (SAS 1996). 


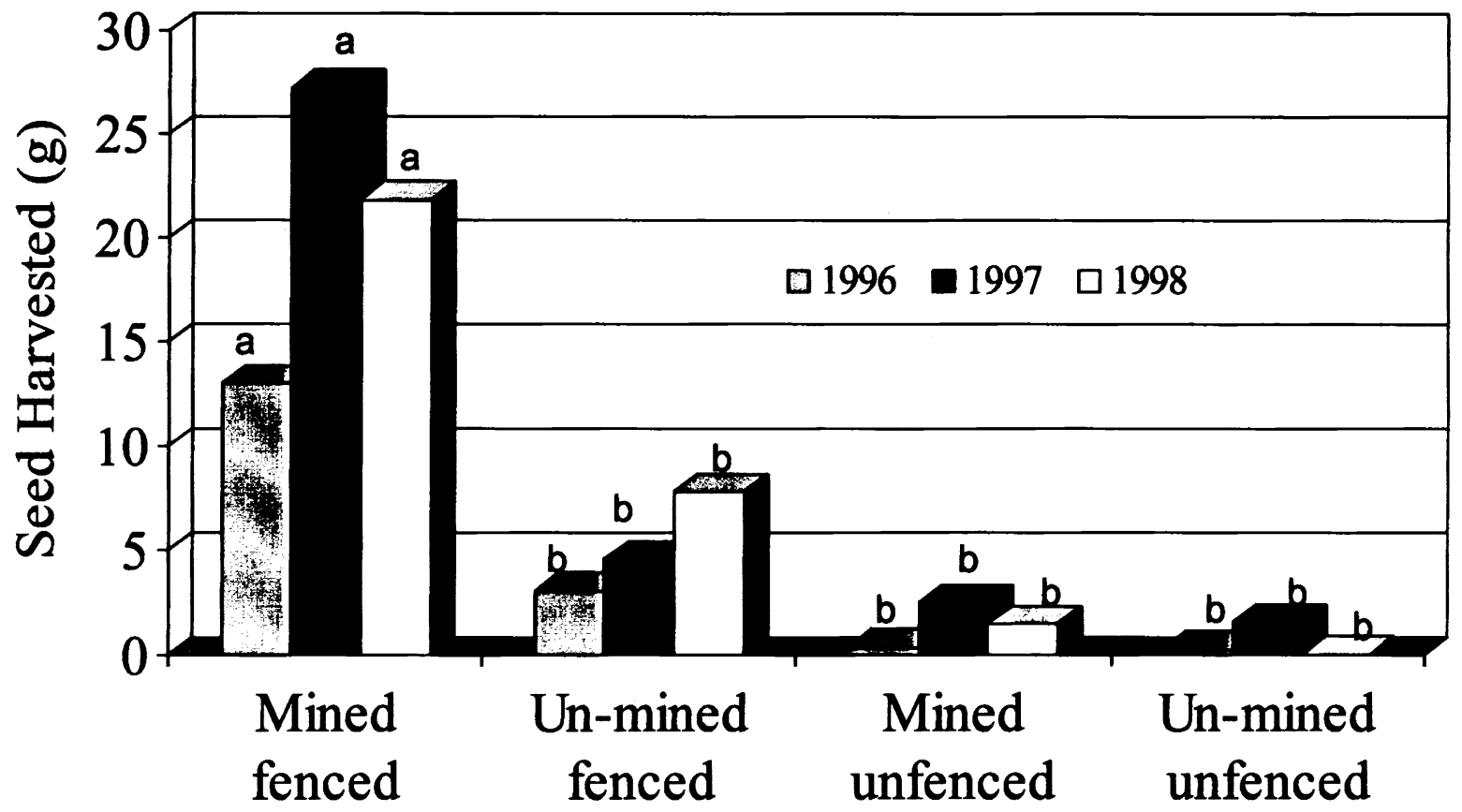

Fig. 1. Mean bulk weight of sagebrush seeds per plant by year as affected by type of land and protective fencing. The OSL for the land $x$ fence interaction was $P=0.03,0.03$, and 0.05 in 1996, 1997, and 1998. Means within a year followed by the same letter are not different at $P<$ 0.05 as indicated by differences in least square means within the "Mixed" statistical procedure (SAS 1996).

\section{Seedling Length - Fenced}

Means for axial length ranged from 23 to $34 \mathrm{~mm}$. (The OSLs: $1996, \mathrm{P}>0.20$ for all variables; 1997 , land $\mathrm{x}$ mulch was $\mathrm{P}=$ 0.07 , mulch $\mathrm{x}$ windbreak was $\mathrm{P}=0.15$, and all others were $P>0.20$. In 1998 land $\mathrm{x}$ windbreak was $\mathrm{P}=0.13$, land $\mathrm{x}$ mulch $\mathrm{x}$ windbreak was $P=0.11$, and all others were $P>0.20$; df: land $=3$, mulch and windbreak $=4$, and interactions $=13$.)

\section{Seedling Length - Unfenced vs Fenced}

There were no differences due to land or fencing in 1997 or $1998(\mathrm{P}>0.57,2$ to 6 df) and in 1996 there were not enough seeds harvested to compare treatments.
Soil Moisture (Fenced Plots Only)

Soil moisture in May was influenced by site $x$ land $x$ mulch $(P=0.05)$, land $x$ mulch $x$ windbreak $(P<0.01)$, year $x$ mulch $(P<0.05)$, year $x$ land $(P<0.01$, and year $\mathrm{x}$ site $(\mathrm{P}<0.01)$ (df for all variables and interactions $=346$ to 354 ). The interactions with site and year were expected. The 3-way interactions (Table 7) reveal that mined-land soils had soil moisture $>$ that of unmined lands. The greatest soil moisture occurred on mined land with mulch and windbreak.

June soil moisture interactions were site $x$ land $(P=0.02)$, year $x$ mulch $(P$ $=0.04)$, and year $\mathrm{x}$ site $(\mathrm{P}<0.01)$. The site $\mathrm{x}$ land data again indicated that minedland soil moisture was $>$ that of that unmined lands (Table 8 ). There were no

Table 6. Seed quality: mean weight of sagebrush seeds by year as affected by land type and mulch ${ }^{1}$.

\begin{tabular}{llccc}
\hline \hline Year & Land Status & Mulch & Seed Weight & OSL \\
\hline \multirow{2}{*}{1996} & & & $(\mathrm{mg} /$ seed $)$ & $\mathrm{P}=0.22$ \\
& Mined & - & 0.21 & \\
1997 & Unmined & - & 0.11 & $\mathrm{P}=0.09$ \\
& Unmined & yes & $0.33 \mathrm{a}$ & \\
& Mined & yes & $0.28 \mathrm{ab}$ & \\
& Mined & no & $0.27 \mathrm{ab}$ & \\
& Unmined & no & $0.24 \mathrm{~b}$ & $\mathrm{P}=0.09$ \\
& - & yes & 0.28 & \\
& - & no & 0.24 &
\end{tabular}

Multiple means within a year followed by the same letter are not different at $\mathrm{P}<0.05$ as indicated by differences in least-square means using the "Mixed" statistical procedure (SAS 1996). Degrees of freedom:land $=4$, mulch $=104$, windbreak $=104$, interactions $=104$. OSL $=$ Observed Significance Level. differences in main effects or interactions for July ( $\mathrm{P}>0.83$ ); and, year $\mathrm{x}$ site was the only significant interaction in August and September $(\mathrm{P}<0.01$ for both months).

\section{Plant Mortality}

There were 3 mined-land plants in the study that died at 110 School $(12.5 \%)$ and 11 that died at 60 Badger $(46 \%)$. (Note the high soil moisture for mined land at 60 Badger (Table 8).) All mortality during the 3 years occurred on mined land; there was no mortality at any of the other study sites.

\section{Discussion}

\section{Land Status - Mined versus Unmined Land}

Seed yields were consistently greater on mined land and the interaction of land $x$ fence resulted in significantly greater seed production than for other treatment combinations. Soil moisture was usually greater under mined-land plants in May and June and that may account for the greater production. Why these soils contained more moisture is a matter for speculation. Conceivably plant density - either of shrubs or of all plants - was lower on mined land. Plant density often affects seed yield and differences in soil moisture may be only 1 aspect of that affect (USDA 1961, Lopez-Bellido et al. 2000, Henderson et al. 2000, Holen et al. 2001). 
Table 7. Mean percentage soil moisture for May averaged over 3 years and as affected by land, mulch, and windbreak.

\begin{tabular}{llccc}
\hline \hline Windbreak & Mulch & Mined & Unmined & OSL $^{1}$ for Land \\
\hline \multirow{2}{*}{ Yes } & Yes & $-1 \%)$ & \\
Yes & No & 59.6 & 62.6 & $<0.01$ \\
& OSL for Mulch & $<0.01$ & $<5.6$ & 0.09 \\
No & Yes & 69.3 & 66.5 & 0.29 \\
No & No & 69.7 & 58.4 & $<0.01$ \\
& OSL for Mulch & 0.87 & $<0.01$ & \\
\hline
\end{tabular}

Observed Significance Level

Seed quality as measured by seed weight, seed moisture, germination, and seedling vigor (axial length) was not affected by land status. Thus, we found no reason to question the quality of minedland seed.

\section{Herbivory - Fenced and Unfenced}

It is clear that large herbivores reduced seed production potential by eating seed stalks (Table 4). Wagstaff and Welch (1991) also reported that protected sagebrush plants produce significantly more seed stalks than plants not protected from grazing animals. We recognize that protective fencing modified the environment in favor of the protected plants. However, the report of Gores (1995), and personal observations of the effects of wildlife herbivory on mined-land shrub stands suggest the bias was relatively insignificant and

Table 8. Mean percentage soil moisture for June averaged over 3 years as affected by site and land.

\begin{tabular}{lccc}
\hline \hline Site & Mined & Unmined & OSL $^{1}$ for Land \\
\hline & $-----(\%)$ & $-\cdots---$ & \\
Fuel Island & 20 & 16 & 0.55 \\
Entry 50 & 36 & 27 & 0.66 \\
110 School & 31 & 37 & 0.36 \\
60 Badger & 70 & 45 & $<0.01$ \\
4 School & 35 & 21 & 0.03 \\
\hline
\end{tabular}

Observed Significance Level

should not be used to under rate wildlife herbivory as a factor limiting seed production of mined-land sagebrush.

\section{Environmental Modification}

We found that surrounding a sagebrush with wire netting (fenced) resulted in a beneficial modification of its environment as evident by greater seed weights from protected plants (Table 4). This was not expected, especially with the large (2.54 $\mathrm{cm}$ ) net used. The fencing affect may account for the minimal effect of mulch and windbreak on seed production and quality and the finding may have implications for those who grow and sell big sagebrush seeds. Mulch and windbreak did influence seed production and quality, but these effects were not as consistent as was the effect of land type, herbivory, or fencing. The mulch did not always result in greater soil moisture (Table 7), probably due to its small size $\left(1 \mathrm{~m}^{2}\right)$. A larger piece of fabric would likely have shown a more consistent benefit to soil moisture (Appleton et al. 1990).

\section{Conclusions and Recommendations}

Wyoming big sagebrush on reclaimed mined lands similar to those of the Dave Johnston Coal Mine have the potential to produce more seeds than plants from adjacent unmined land. However, the minedland seed-production advantage will be realized only when the plants are protected from browsing wildlife. Environmental modification can also improve seed production and some factors of seed quality, but these efforts are viewed as more expensive and less effective than excluding browsing animals.

\section{Literature Cited}

Appleton, B.L., J.F. Derr, and B.B. Ross. 1990. The effect of various landscape weed control measures on soil moisture and temperature, and tree root growth. J. Arboculture 16:264-268.

Bai, Y., D.T. Booth, and E.E. Roos. 1997. Effect of seed moisture on Wyoming big sagebrush seed quality. J. Range Manage. $50: 419-422$.

Booth, D.T. and Y. Bai. 1999. Effects of imbibition temperature on seedling vigor: comparison among crops and rangeland shrubs. J. Range Manage. 52:534-538.

Booth, D.T. and L.W. Griffith. 1994. Measuring post-germination growth. J. Range Manage. 47:503-504.

Booth, D.T., J.K. Gores, R.A. Olson, and G.E. Schuman. 1999. Shrub densities on pre-1985 reclaimed mine lands in Wyoming. Restoration Ecol. 7:24-32.

Booth, G.D. 1987. Interpreting statistical tests. Statistical Notes. Sept. 10:47-49 (USDA, Forest Serv. Intermountain, Res. Sta., Ogden, Ut.).

DEQ-LQD (Dept. Of Environmental Quality - Land Quality Division). 1995. Coal rules and regulations. State of Wyoming, Cheyenne, Wyo.

Federal Register. 1996. Office of Surface Mining and Enforcement. 30 CFR Part 950. Wyoming Regulator Program, final rule; approval of amendment. 61(152):40735.

Gores, J.D. 1995. The evaluation of big sagebrush and fourwing saltbush establishment on pre-1985 Wyoming reclaimed mine sites. M.S. Thesis. Univ. Wyoming, Laramie, Wyo.

Henderson, T.L., B.L. Johnson, and A.A. Schneiter. 2000. Row spacing, plant population, and cultivar effects on grain amaranth in the Northern Great Plains. Agron. J. 92:329-336.

Holen, D.L., P.L. Bruckner, J.M. Martin, G.R. Carlson, D.M. Wichman, and J.E. Berg. 2001. Response of winter wheat to simulated stand reduction. Agron. J. 93:364-370 .

Jones, L.G. and R.D. Cobb. 1963. A technique for increasing the speed of laboratory germination testing. Proc. Assoc. Offic. Seed Analysts. 53:144-160.

Littell, R.C., G.A. Milliken, W.W. Stroup, and R.D. Wolfinger. 1996. SAS system for mixed models. SAS Institute Inc. Cary, N.C.

Lopez-Bellido, L., M. Fuentes, and J.E. Castillo. 2000. Growth and yield of white lupin under Mediterranean conditions. Agron. J. 92:200-205.

Lyford, M.E. 1995. Shrub establishment on drastically disturbed lands. M.S. Thesis. Univ. of Wyoming, Laramie, Wyo.

Martner, B.E. 1986. Wyoming climate atlas. University of Nebraska Press, Lincoln, Nebr.

Owenby, J.R. and D.S. Ezell. 1992. Monthly station normals of temperature, precipitation, and heating and cooling degree days, 1961-1990 for Wyoming. National Climatic Data Center, Asheville, N.C.

SAS. 1996. SAS / STAT software: changes and enhancements through release 6.11. SAS Institute Inc., Cary, N.C.

USDA. 1961. Seeds - The yearbook of agriculture. U.S. Government Printing Office, Washington, D.C.

Wagstaff, F.J. and B.L. Welch. 1991. Seedstalk production of mountain big sagebrush enhanced through short-term protection from heavy browsing. J. Range Manage. 44:72-74

WEQC (Wyoming Environmental Quality Council). 1995. In the matter of the proposed revision of the Land Quality Division rules related to the regulation of coal mining: statement of principal reasons for adoption. State of Wyoming, Cheyenne, Wyo.

Young, J.F. and P.C. Singleton. 1977. Wyoming general soil map. Wyoming Agr. Exp. Stat. Bull. Research Journal 117, Univ. of Wyoming, Laramie. 